Nikolett Kovács - Ildikó Vaskó (Budapest):

\title{
The Telltale Sentence Structure
}

\section{Introduction}

There are several clues that can disclose you are not using your mother tongue. Pronunciation, especially intonation, lexical items that do not fit into the given context, or even the simplest grammatical mistake, the lack of agreement or using an incorrect article, among others. However, it is very often the faulty sentence structure that reveals that the speaker is not using his/her first language.

First-year students at the Department of Scandinavian Studies at Eötvös Loránd University start their university studies without preliminary knowledge of Danish, Norwegian, or Swedish; therefore, great emphasis is placed on the acquisition of the target language especially in the beginning of the curriculum.

It is essential for successful university admission to master a first foreign language (English and/or German that is an L2 and/or L3), consequently Danish, Norwegian, and Swedish are regarded as L3 or L4 at our department. Our research focuses on how effectively Norwegian is acquired, based on the evaluation of the results of the written proficiency exams in Norwegian by firstyear students in the past 7 years. This research provides insight into what typical grammar mistakes are made by first-year students of Norwegian after completing a one-year intensive language course, with special attention to syntactic features.

\section{Research Purpose}

Our aim is to answer the following research questions:

1) What linguistic peculiarities pose the greatest challenges to students?

2) What influence does Hungarian as students' L1 and their foreign languages have on acquiring Norwegian?

Most students have already studied English or German, in some cases both, and reached a lower or higher level of language knowledge. Studying a Scandinavian language at university is something special and more than just learning a language, as students have only one year of intensive language learning to reach the level required for the proficiency exam and continue their university career. As a consequence, we might assume that in this case, acquiring Norwegian - which is not the first foreign language of these students can be easier since they have already some experience in language learning. This is indeed a valid question whether the knowledge of these languages mentioned above can really prove helpful to students. English and German 
together with the Scandinavian languages belong to the Germanic languages, English and German to the West Germanic ones, while Norwegian to the North Germanic ones. Obviously, vocabulary as well as a large part of the grammar share similarities with the above languages. Taking all this into consideration, can we really expect a dynamic development regarding the efficiency of language learning, and can we avoid grammatical difficulties based on the already existing L2 language knowledge?

By processing the available data, i.e. the results of the written proficiency examinations from the last seven years, it seems quite apparent that problems concerning sentence structure are among the most demanding tasks. The syntactic mistakes are common not only in grammar exercises but also in translation and text formation tasks. In recent years, the different tested skills and competence regarding the use of prepositions, adjectives, etc. have not shown stable or balanced results at all. It is striking that German or English characteristics of sentence structures are overwhelming; moreover, students often overcomplicate the sentence structures. We can hardly disregard the fact that, according to the statistics, the quality of translation in comparison with other skills does not show an improving tendency. Based on these observations, we have decided to focus our research on challenges sentence structures may cause for our students. It is especially in two tasks where students' ability to form grammatically correct sentence can be investigated: essay writing and translation from L1.

\section{Theoretical Background: Complexity, Accuracy, Fluency}

In recent years, there have been several attempts to model difficulties in second language learning. In the study of syntactic complexity, we have relied on CAF theories (Complexity, Accuracy, Fluency) theories of Skehan (1998), Ellis (2009), and Berggreen, H., Sørland, K. (2016). Berggreen and Tenfjord (1999) formulate in general how a 'weak' use of language becomes 'strong' among language learners.

CAF tradition - as part of the research in second language acquisition - has the aim to show and measure students' development in grammar, grammatical rules in general. This can be traced back to the 1960s and 1970s, when the studies by Hunt $(1965,1966)$ and Larsen- Freeman (1977) played a central role in CAF tradition. Housen and Kuiken briefly summarize the main points of this method: "CAF have been used both as performance descriptors for the oral and written assessment of language learners as well as indicators of learners' proficiency underlying their performance; they have also been used for measuring progress in language learning” (2009:461). In the 1980s, the difference between fluency and accuracy as well as oral proficiency development were already highlighted in L2 usage in the classroom. Brumfit (1979) was among the first ones to apply the dichotomy of fluency and 
accuracy. Later, Skehan (1989) worked out a more nuanced theory and thanks to his work, fluency and accuracy were complemented by the notion of complexity and he was the first to use these three components or dimensions called the CAF triad. The accurate definitions of the terms used today spread broadly in the 1990s. These dimensions cover the different fields of a language in a wide spectrum. The borders between the concepts cannot be sharply distinguished; even linguists are divided in this regard. Complexity refers to the sophistication, richness, and diversity of L2 (Ellis 2003, Housen and Kuiken, 2009). Accuracy serves to measure the compliance with target language standards and language usage free from mistakes (Wolfe-Quintero, 1998). Fluency is certainly suitable to test spoken language, where students' language levels are measured based on smoothness, hesitation, breaks and rewording (Chambers 1997, Lennon 1990). The elements of the trio influence one another, that is why Wolfe-Quinero (1998) suggested that all of them should be paid attention to when a second language learner's progress is taken into consideration. These dimensions are diversified and complicated and are not necessarily connected to each other in a linear way (Larsen-Freeman 2009, Norris and Ortega 2009). Ellis (1994, 2003) and several further researchers (Skehan 1998, Skehan and Foster 1999) agree that in L2 acquisition, fluency can improve at the expense of accuracy and complexity.

\subsection{Complexity}

Complexity is regarded as one of the most controversial dimensions of the CAF construction (Norris and Ortega 2009, Pallotti 2009, 2015). According to the definition of Ellis and Barkhuizen (2005), language learners can use the acquired foreign language precisely and accurately. Complexity applies to different aspects of SLA (second language acquisition), e.g. developmental complexity, cognitive complexity, linguistic complexity. The latter one itself is a multidimensional concept. According to Bulté and Housen (2012), complexity requires an extremely complex cognitive knowledge from language learners. Both Ellis and Barkhuizen (2005) and Bulté and Housen (2012) make a fundamental distinction between lexical (variety, elaborateness) and grammatical complexity - e.g. morphology, syntax - (length, diversity, interdependence). The latter one also has subcategories, e.g. attributive structures, dependent clauses, coordination.

\subsection{Accuracy}

Several researchers (Housen and Kuiken 2009, Palloti 2009) regard this dimension as the most transparent one out of the three. It measures the degree of deviancy from the norms of the target language both written and orally and encompasses the various properties of language performance (see figure 1.). 


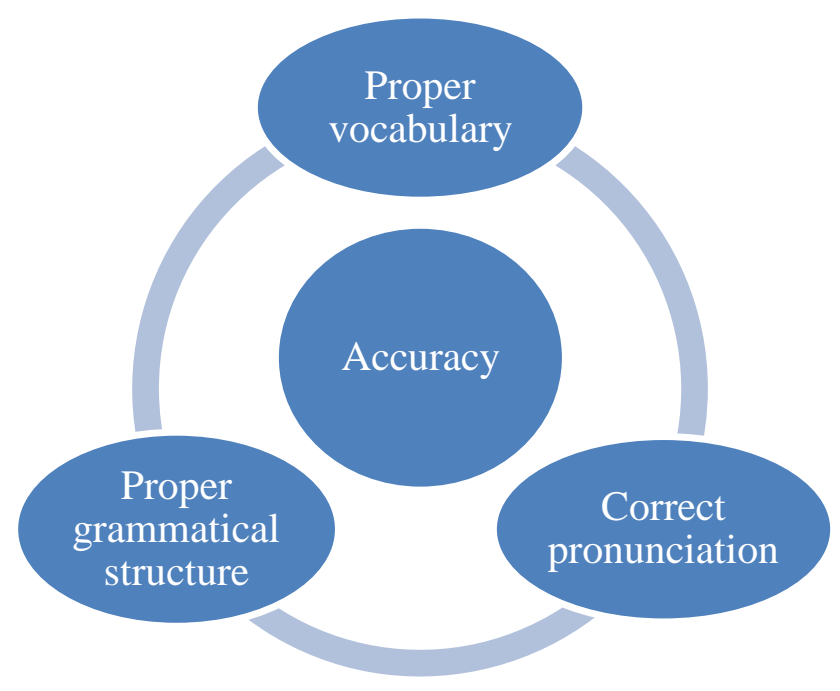

Figure 1. Accuracy

This area is formed by correctly chosen words, correct pronunciation as well as correct grammatical structure. However, the situation is not clear as there are languages with more normative rules than in others, e.g. German (Kuiken and Vedder 2007). Kuiken and Vedder categorized various errors in the dimension of accuracy: minor mistakes (grade 1), e.g. spelling mistakes, lack of articles; more serious mistakes impeding understanding (grade 2) e.g. word order errors; category of incomprehensible sentences (grade 3) e.g. incorrect word choice, grammar mistake.

\subsection{Fluency}

This is the last component of the CAF triad, which is - by its very nature mainly the measure of spoken language, although this dimension is tried to be assessed in writing, too, using computer software. Tavakoli and Skehan (2005) listed the components of fluency as follows: speed, breakdown (pauses and silences) and repair (repetitions and reformulations).

Norris and Ortega (2009) stated that L2 users most probably would not speak fluently in case of more complex tasks. Furthermore, they believe that repeating the exercise once could enhance fluency. If it is repeated several times, then it has a positive effect on both accuracy and complexity. So, language learners can overcome the difficulties in these dimensions and achieve a higher language level. Regarding Hungarian L1 learners acquiring a foreign language Bárdos (2000) also reflects on this contrast: 'Egymásba kapaszkodó kettösségük mögött természetesen felfedezhetjük a nyelvi pontosság, korrektség, illetve a beszéd folyamatosságának, sebességének örökzöld ellentétét (accuracy vs. fluency) ${ }^{1}$, (2000, p. 58).

\footnotetext{
Behind their dichotomy clinging to each other we can discover the evergreen contrast of grammar accuracy
} and speaking fluency and speed (accuracy vs. fluency) (2000, p. 58.) 
The CAF triad covers the measurement of foreign language competency on a wide spectrum; nevertheless, in this survey we concentrate on word order, complex sentences and noun phrases within the dimension of complexity and grammar accuracy within the dimension of accuracy since, based on our investigated data, students of Norwegian have difficulties with these.

\section{Research}

Our research focuses on identifying the areas causing problems to learners of Norwegian, and then on finding methods that can be effective to cope with grammar difficulties. Students' previously acquired knowledge of L2 as well as the influence of the mother tongue on the acquisition of the target language are all regarded as key aspects.

As mentioned previously students of Norwegian at our department are usually familiar with English and/or German. They have learned these languages at different levels, so they already have some experience in foreign language learning. We would expect this advantage to accelerate the acquisition of Norwegian as we assume that previous experience has a positive influence on learning Norwegian. Moreover, we also suppose that the grammatical differences between the mother tongue and Norwegian can be better surmounted with a knowledge of English and/or German because these languages share similarities as far as sentence structure is concerned.

Carliste (1989) pointed out that multilingual students have significantly better results due to their wider understanding of and experience with syntactic structures. On the other hand, there are cases where exactly the knowledge of English/German can create certain problems in acquiring Norwegian as L3 or L4. Bohnacker (2006, 2007) conducted research in this field. He argues for full transfer (FTFA - Full Transfer Full Access Hypothesis) and presents how languages influence each other. He specifies to what extent the already existing L2 affects L3/L4 acquisition. Bohnacker points out that there is transfer from the native language not only in the VP (verb phrase). He divided a group of native Swedes learning German based on the degree V2 (according to V2 principle the second position of the sentence must be occupied by the finite verb) was applied, whether this grammatical rule was used correctly in the initial phase, or not. The research reveals the fact that those making mistakes in V2 had learnt English before. Those relying on their mother tongue only but not on English did not make such word order mistakes. Consequently, learners' linguistic competence in English do have an impact on the acquisition of German in this case. For similar cases see among others, De Angelis (2007) and Leung (2009), who also dealt with mastering L3 and L4 as well as the influence of foreign languages and the mother tongue on L3 and L4.

Students studying Norwegian have to take a proficiency language test at the end of the first university year, during which they use the monolingual 
coursebook På vei ${ }^{2}$. According to the description of the textbook, the target is to achieve level A2 of the Common European Framework of Reference for Languages. The proficiency language exam consists of a written and an oral part. We will discuss only the results of the written part. Although the exam has to include tasks of similar difficulty and nature, nevertheless the concrete tasks should be different every year. The written exam takes 90 minutes which usually proves to be enough for students to complete the tasks.

All in all, we have investigated 112 examination tests from the past 7 years. These proficiency language exams were taken by students who studied Norwegian for one year with the aim of reaching level A2. Based on the processed data, it can be concluded that the average overall score is between $73 \%$ and $83 \%$ which is considered to be a good achievement. The results are illustrated by Figure 2 below.

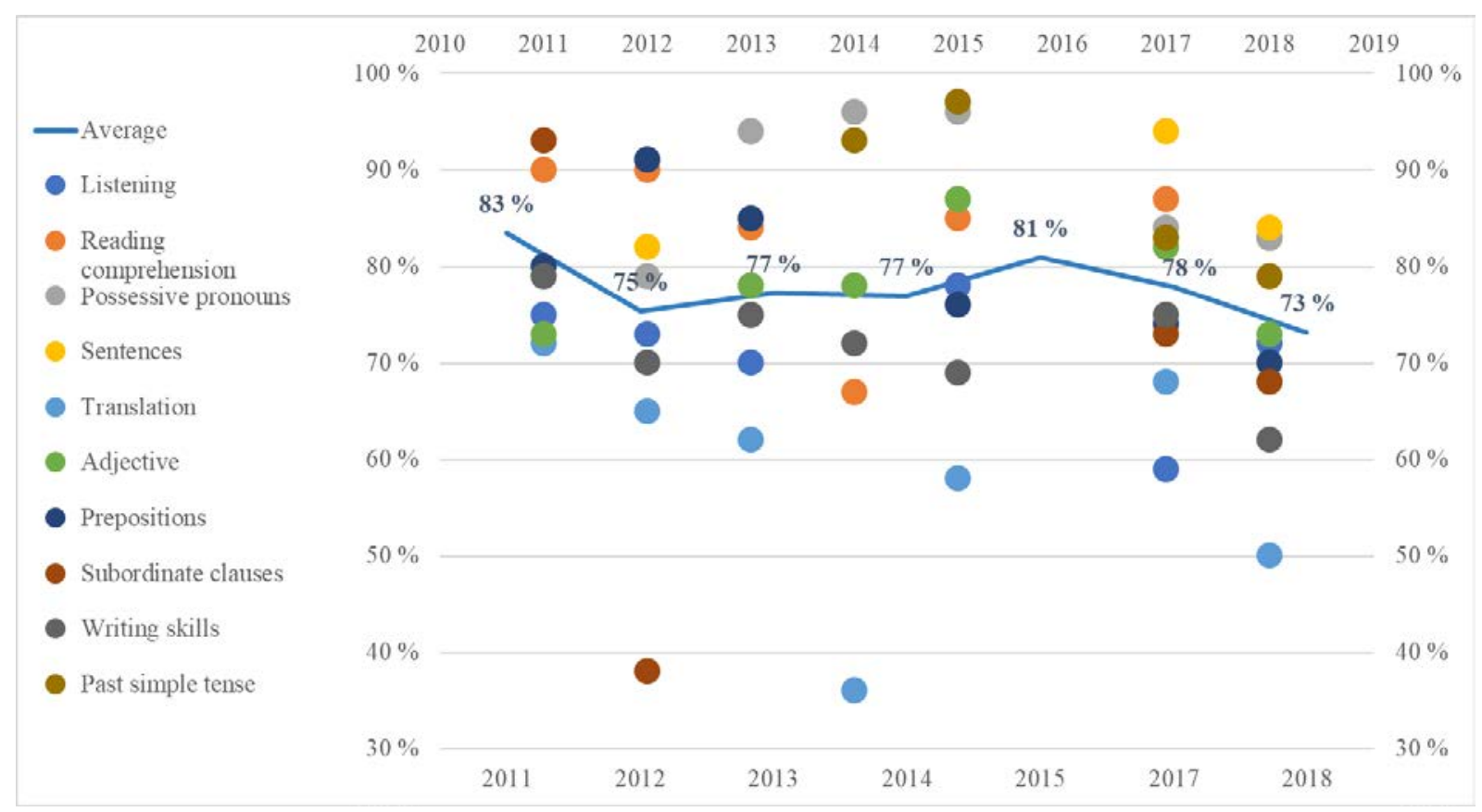

Figure 2. Test results

However, a closer look at the different task types reveals that the results of certain tasks display a fluctuating tendency, whereas some other task types produce quite balanced ones. Those task types are of interest, where the outcomes in different years do not show any similarities, i.e. their standard deviation is wider:

2 På vei (2012) Norsk og samfunnskunnskap for voksne innvandrere, authors: Elisabeth Ellingsen and Kirsti Mac Donald 


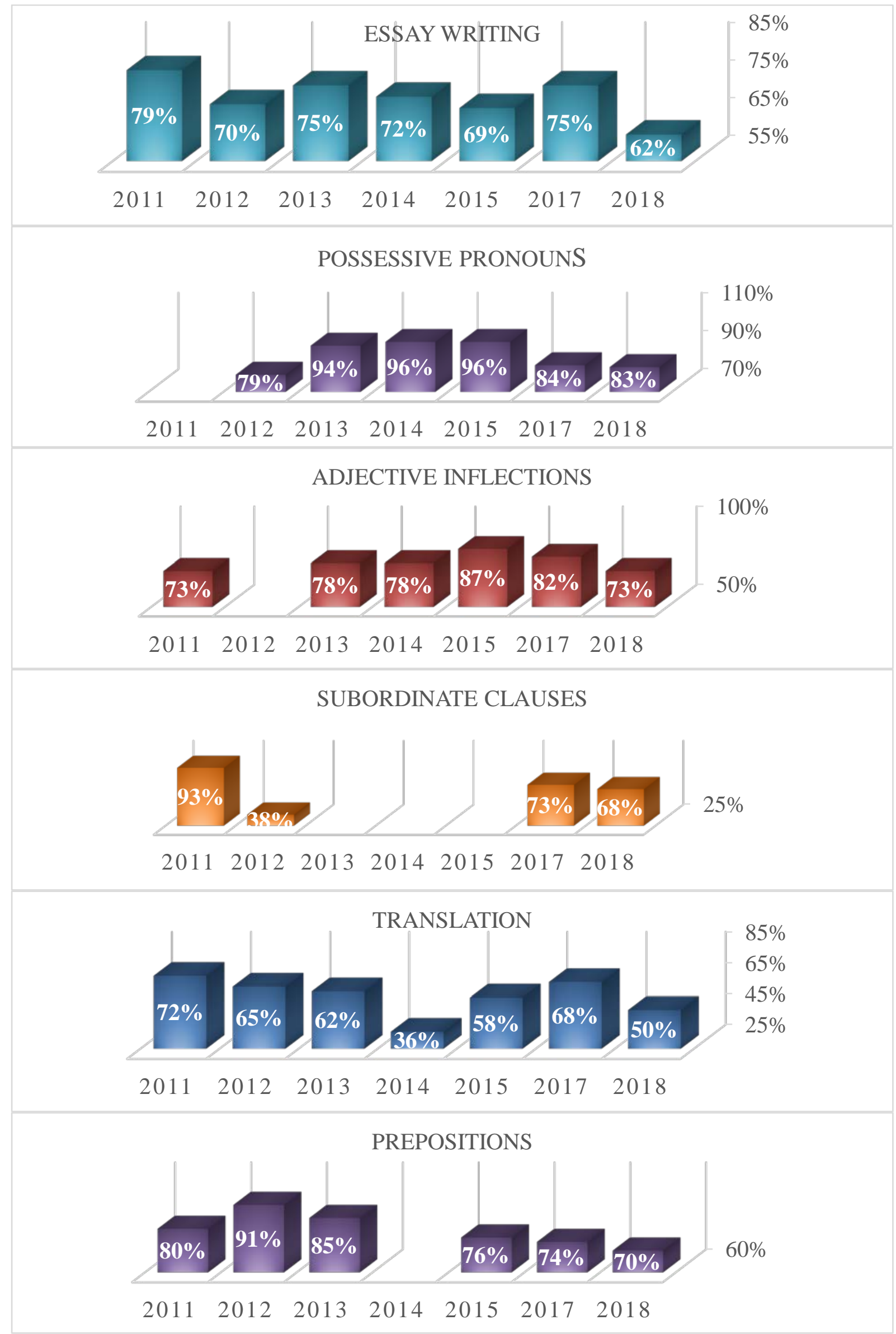

Figure 3 Test results in details 
According to Berggreen and Sørland (2016), it is best to evaluate students' development in writing after the first and second year. As the essay writing diagram depicts, students face difficulties in text formation, they use both grammatically and idiomatically incorrect structures. The further diagrams represent which fields within syntactic complexity and grammatical accuracy should be improved in the following years, e.g. word order in subordinate clauses, adjective declension in noun phrases, definite/indefinite items, use of prepositions, possessive pronouns. The task of translation shows various results. Translation and essay writing presumes a solid knowledge of grammar, which enables students to form grammatically correct Norwegian sentences. The other diagrams show how problematic certain pieces of grammar are to students.

Most students are faced with problems with word order in subordinate clauses, especially in the case of negation or sentence adverbs: * Jeg går ikke på kino fordi jeg har ikke lyst. ${ }^{3}$, ${ }^{*}$ Hun sier at hun går ofte på trening. ${ }^{4}$ Another typical mistake in connection with subordinate clauses is the use of relative pronouns as conjunction and the word order after that. In these cases, too, students often use the interrogative word order introduced by a question word: * Hun spør når kommer bussen. ${ }^{5}$ Jeg vet ikke hvor bor de ${ }^{6}$. The sentences above combined with negation create problems, too: ${ }^{*}$ Jeg vet ikke hvorfor de kommer ikke $^{7}$ or ${ }^{*}$ Jeg vet ikke hvorfor kommer de ikke. ${ }^{8}$ Presumably, this kind of error also belongs to the group of intralingual ones, as similar agrammatical examples can be observed with students of different mother tongue (cf. Eckemann 1977, 1985). In other words, this field is probably more marked in Norwegian than in the native language that is why it can lead to trouble.

The correct choice of prepositions means generally a great challenge in most languages as their use are always language-specific. It can be particularly puzzling for a speaker whose L1 does not employ a prepositional system.

There are a number of error sources in case of possessive structures, since it is not only the s-genitive typical of Germanic languages to express genitive but there are other ways, too, such as using different prepositions or reflexive possessive pronouns. Moreover, it is also specified whether the definite or the indefinite form of the noun phrase should be used.

On the other hand, Hungarian can help in cases when the definite and indefinite forms of nouns have to be used in sentences, as Hungarian distinguishes definite and indefinite forms, applying general cognitive rules.

Anteposition - e.g. a sentence with an adverb in the first position - clearly illustrates word order errors. Students often commit errors by not following the

\footnotetext{
Correctly: Jeg går ikke på kino fordi jeg ikke har lyst. (I don’t go to the movie, because I don’t want to.)

Correctly: Hun sier at hun ofte går på trening. (She says she often goes to training.)

Correctly: Hun spør når bussen kommer. (She asks when the bus comes.)

Correctly: Jeg vet ikke hvor de bor. (I don't know where they live.)

Correctly: Jeg vet ikke hvorfor de ikke kommer. (I don't know why they don't come.)

Correctly: Jeg vet ikke hvorfor de ikke kommer. (I don't know why they don't come.)
} 
V2 rule, that is by not using the compulsory inversion: *Etterpå jeg går på jobb. ${ }^{9}$ ${ }^{*}$ Etter frokost jeg pusser tennene ${ }^{10}$. This rule applies in German, too (Dann gehe ich arbeiten.) as opposed to English (Afterwards I go to work.), so students who had studied German would be supposed to make such mistakes less often. As a number of languages do not have a V2 word order, this grammar rule causes trouble in most cases. It is important to mention the study by Næss (2006), which demonstrates the fact that English as well as Thai and Persian native learners make the mistakes discussed above with an already existing knowledge of English in contrast to French native learners who do not speak English. This originates from the fact that the V2 rule does not apply in English, therefore learners mastering English can often make a word order error by not placing the conjugated verb in the second position. The V2 rule is one of the characteristics or parameters of Norwegian.

Skehan points out the missing native language data in CAF research, which can play a significant role serving as a starting point for comparing the development of L2 learners. Returning to the idea by Housen and Kuiken, CAF research draws attention to the measurement of language learners' progress as well as achievement while it does not come up with an explanation for the reason why recurring errors persist. In the following section, we try to find answers how the mother tongue and the already existing L2 and L3 of learners of Norwegian influence the target language.

\subsection{How the Mother Tongue Influences Second Language Acquisition}

In his study on the method of Contrastive Analysis, Robert Lado (1957) claims that second language learning difficulties can be found in differences and similarities that emerge when comparing L1 and L2. According to Lado, these help to predict what fields in the target language will cause problems. He formulated the idea of positive transfer (same language structures in L1 and L2, thus easy to learn) and negative transfer (differences that lead to agrammatical forms in the second language). Later, contrastive analysis was replaced by Error Analysis (EA) in the 1970s, which focused on error types, more precisely interlingual (native language interference) and intralingual errors (irrespective of the mother tongue, resulting from the properties of the target language). This method was criticised for dealing exclusively with errors, while the lack of errors can be due to omitting problematic items of grammar and not to learners' adequate competence. The previous two methods were succeeded by interlanguage studies. Selinker (1972) was the first to use this term. In his views, certain elements of interlanguage come from the native language, others from the target one, undergoing constant change since some elements are added while

9 Correctly: Etterpå går jeg på jobb. (Afterwards I go to work.)

10 Correctly: Etter frokost pusser jeg tennene. (After breakfast, I brush my teeth.) 
others are removed. As a consequence, this language form is more changeable and less stable than the native language, going through several phases step by step. L2 learners rarely achieve the level of native speakers. Linguists have always been engaged in finding out to what extent and how mother tongue influences L2 acquisition and have produced a lot of theories in this field. Berggreen and Tenfjord (2011) share Selinker's view that the mother tongue has an impact on acquiring the target language, i.e. the native language serves as a determining pattern during $\mathrm{L} 2$ acquisition.

Native Language Transfer has been researched extensively for a long time, resulting in conflicting theories. Uriel Weinreich (1953) held the view that negative transfer should be stressed instead of the positive impact. In contrast, Ringbom (1987, 1992) claimed the opposite: positive transfer plays a crucial role because the similarities between L1 and L2 have more influence on the speed of interlanguage development. This is the key to successful L2 acquisition. Accordingly, vocabulary or related vocabulary is important and helpful in understanding. This is why students of German and/or English soon find out the meaning of words that resemble those they already know in another foreign language. Moreover, their passive knowledge can also be greater than that of other students.

The Markedness Differential Hypothesis by Eckeman $(1977,1985)$ can explain why the grammar errors in Norwegian presented above cause difficulties. According to this theory, the more typical and frequent language form is regarded as unmarked, while the rarer, more specific and complex forms as marked. He claims if an area in L1 is more marked, i.e. more complex and exceptional, than in the target language, the given phenomenon will not make any particular difficulties to the learners and mother tongue transfer will not take place. However, if it is more marked in the target language, in our case, Norwegian, mastering that special area will be more difficult for learners. Ringbom (1987) and Elo (1993) think it is obvious that the similarities in vocabulary or structures between the native and the target languages accelerate interlanguage development.

Research by Schumann (1979) supports our assumption that students' negation errors in Norwegian are related to their mother tongue. In connection with learning English, Schumann points out that students whose mother tongue lacks preverbal negation (German, Norwegian) can easily avoid the error of 'no + verb' structures. This assumption can also be considered from the opposite side, as similar problems arise in the tests we examined, even though they were not written by native Spanish speakers, like in Schumann's article, but by Hungarian learners. Preverbal negation is used in Hungarian as well, which leads to considerable difficulties in verb negation in Norwegian to students since the Norwegian verb phrase structure is different. Consequently, this error type is interlingual, it originates from mother tongue interference. This is the reason why the following agrammatical sentences occur in writing tests: ${ }^{*}$ Jeg ikke 
snakker spansk ${ }^{11}$. *Jeg ikke går på kino ${ }^{12}$. The problems with negation can be observed already in the first semester and occur even after repeated exercises. What is more, they can be found in the elementary exam at the end of the first year, too. However, it is also worth noticing that in subordinate clauses in Norwegian, negative particles have to be placed before the conjugated verb. Although this is similar to the Hungarian word order, though, it still seems to be a common mistake as illustrated earlier (footnotes 3-8). It could be explained by several reasons: by the time students learn negative subordinate clauses, they have already acquired the rule adequately that in simple sentences, the negative particle follows the conjugated verb. Another explanation could be the fact that this area is more marked in the grammar of the target language than in the native one, so it is harder for students to learn. This grammatical error often occurs in case of learners with different mother tongues as well, therefore it could be an intralingual error.

A number of theories on the role of mother tongue and universal grammar (UG) in L2/L2/L4 acquisition have been put forward in the past 20 years. Some of these are highlighted in the following paragraph with particular attention to conflicting ones.

According to the Minimal Trees Hypothesis by Vainikka and Young-Scholten (1994, 1996a, 1996b), mother tongue transfer is characteristic only of the initial phase of language learning and only in a certain area, in the Verb Phrases (VP). In other words, functional features are formed only in a later stage. In short, everything outside VP develops only later on and not with the help of mother tongue transfer. This assumption is based on UG theory, an improved version of Chomsky's hypothesis (1981, 1986). In his study on universal grammar, Andrew Carnie (2006) claims, as well, that one has a cognitive ability specialized in language and its acquisition. This is a special linguistic ability connected to hierarchical organization but not to surface, linear order. This enables us to know such things about our language which we have not learnt explicitly. It is a matter for debate what and how much this special linguistic ability covers exactly. We do not know where it is located in our brain or if it is coded in a linguistic gene. Meisel (2011) gives a comprehensive picture of L1 and L2 acquisition, claiming that the previously mentioned language ability born with us enables us to acquire a language, no matter which. The role of UG in L2/L3/L4 acquisition is under debate. Do language learners have access to UG in the same way as with their mother tongue? How deep is the impact of the native language, in other words, what is the starting point in case of L2: UG, mother tongue transfer or both? These are questions that are still open to debate.

11 Correctly: Jeg snakker ikke spansk. (I can’t speak Spanish.)

12 Correctly: Jeg går ikke på kino. (I don't go to the movie.) 


\section{Conclusions}

This article draws attention to typical mistakes made by first-year students of Norwegian. There are several grammar resources to help acquire Norwegian syntax correctly. The sentence scheme by Paul Diderichsen (1946) proves to be a suitable starting point. Among modern linguists, the research by Svein Lie (1984) should be mentioned, who continued the tradition of Diderichsen, and the work of Tor Anders Affarli (2003), who explains the characteristics of Norwegian within generative linguistics. Svein Lie sums up the grammar rules of Norwegian sentence structure in his book Innføring i norsk syntaks. With this help, students get a deeper insight into Norwegian grammar. However, these excellent studies do not provide a solution for overcoming all difficulties in grammar.

The telltale sentence structure reveals several specific problems that is due L1 or L2 transfer. These demanding parts of grammar that we pinpointed in the proficiency tests should get particular attention during the language courses making students aware of possible linguistic influences.

\section{References}

Bárdos, J. (2000). Az Idegen nyelvek tanításának elméleti alapjai és gyakorlata. Nemzeti Tankönyvkiadó, Budapest

Berggreen, H., Sørland, K. (2016). Syntaktisk kompleksitet i et skriftlig innlærerspråkmateriale. NOA norsk som andrespråk · Årgang 32 • 1-2/2016 31-75.

Berggreen, H., Tenfjord, K. (1999). Andrespråkslæring. Oslo: Gyldendal Akademisk.

Bohnacker, U. (2006). When Swedes begin to learn German: from V2 to V2, Second Language research 22: 443-486.

Bohnacker, U. (2007). On the 'Vulnerability' of Syntactic Domains in Swedish and German, Language Acquisition 14: 31-73.

Brumfit, C. (1979). Communicative language teaching: An educational perspective. In C. J. Brumfit \& K. Johnson (Eds.), The communicative approach to language teaching, 183-191. Oxford: Oxford University Press.

Bulté, B., \& Housen, A. (2012). Defining and operationalising L2 complexity. In A. Housen, F. Kuiken \& I. Vedder (Eds.), Dimensions of L2 Performance and Proficiency: Complexity, Accuracy and Fluency in SLA, (pp. 23-46). Amsterdam/Philadelphia: John Benjamins.

Carliste, Robert S. (1989). The Writing of Anglo and Hispanic Elementary School Students in Bilingual, Submersion, and Regular Programs. Studies in Second Syntaktisk kompleksitet i et skriftlig innlærerspråkmateriale, Harald Berggreen og Kjartan SørlandCarnie, A. (2006). Syntax, A Generative Introduction Second Edition, 1-30.

Carnie, A. (2006). Syntax, A Generative Introduction Second Edition, 1-30.

Chambers, F. (1997). What do we mean by oral fluency? System 25: 535-544.

Chomsky, N. (1981). Lectures on Government and Binding. The Pisa Lectures, Dordrecht: Foris.

Chomsky, N. (1986). Knowledge of Language. Its Nature, Origin, and Use, New York: Praeger. 
De Angelis, G. (2007) Third or Additional Language Acquisition, Clevedon: Multilingual Matters.

Eckeman, F. (1977). Markedness and the Contrastive Analysis Hypothesis. Language Learning 27, 315-330

Eckeman, F. (1985). The Markedness Differential Hypothesis: Theory and applications. In: B. Wheatly - A. Hastings - F. Eckman - L. Bell - G. Krukar - R. Rutkowski (ed.) Current Approaches to Second Language Acquisition: Proceedings of the 1984 University of Wisconsin-Milwaukee Linguistics Symposium. Bloomington, IN: Indiana University Linguistics Club. 3-10

Eide, M. K. (red.) (2015). Norsk andrespråkssyntaks, 59-133

Ellis, R. (1994). A Theory of Instructed Second Language Acquisition in Ellis, N. (ed.): Implicit and Explicit Learning of Language. London: Academic Press.

Ellis, R. (2003). Task-based Language Learning and Teaching. Oxford University Press.

Ellis, R., Barkhuizen, G. (2005). Analysing Learner Language. Oxford University Press.

Ellis, R. (2009). Task-based Language Teaching: Sorting out the Misunderstandings. International Journal of Applied Linguistics Vol. 19, 3. pp: 229-246.

Elo, A. (1993). Le français parlé par les étudiants finnophones et suedophones. Doctoral dissertation, University of Turku.

Foster, P. \& Skehan, P. (1999). The effect of source of planning and focus on planning on task-based performance. Language Teaching Research, 3 (3), 185-215.

Housen, A., Kuiken, F. (2009). Complexity, Accuracy, and Fluency in Second Language Acquisition. Applied Linguistics, årg. 30, nr. 4. (461-473). Oxford: Oxford University Press.

Hunt, K (1965). Grammatical structures written at three grade levels. NCTE Research Report No. 3. Illinois: National Council of Teachers of English.

Hunt, K. (1966). Recent Measures in Syntactic Development. Elementary English, årg. 43,nr.7. Illinois: National Council of Teachers of English.

Kuiken, F. \& I. Vedder. (2007). Task complexity and measures of linguistic performance in L2 writing. International Review of Applied Linguistics in Language Teaching 45/3: 261284.

Lado, R. (1957). Linguistics Across Cultures. Ann Arbor, MI: University of Michigan Press.

Larsen-Freeman, D., Storm, V. (1977). The Construction of a Second Language Acquisition Index of Development. Language Learning årg. 27, nr. 1. 123-134.

Larsen-Freeman, D. (2006). The Emergence of Complexity, Fluency, and Accuracy in the Oral and Written Production of Five Chinese Learners of English. Applied Linguistics, årg. 27, nr. 4. 590-619. Oxford: Oxford University Press.

Larsen Freeman, D. (2009). The Emergence of Complexity, Fluency, and Accuracy in the Oral and Written Production of Five Chinese Learners of English. Applied Linguistics, 30(4), 590-619.

Lennon, P. (1990). Investigating fluency in EFL: A quantative approach. Language Learning 40: 387-417.

Leung, Y.-K. I. (red.) (2009) Third Language Acquisition and Universal Grammar, Bristol: Multilingual Matters.

Lie, S. (1984). Innføring i norsk syntaks. Universitetsforlaget AS, Oslo

Meisel, J.M. (2011). First and second Language Acquisition, Cambridge: Cambridge Univerity Press

Norris, J. M., \& Ortega, L. (2009). Towards an organic approach to investigating CAF in instructed SLA: The case of complexity. Applied Linguistics, 30 (4), 555-578.

Næss, S.M. (2006) Kan han snakker norsk? En generativ analyse av ja/nei-spørsmål i norsk som andrespråk. Mastergradsoppåve, INL NTNU. 
Pallotti, G. (2009). CAF: Defining, Refining and Differentiating Constructs. Applied Linguistics, 30(4), 590-601.

Pallotti, G. (2015). A simple view of linguistic complexity. Second Language Research, 31 (1), 117-134.

Ringbom, H. (1987). The role of the first language in foreign language learning. Clevedon: Multilingual Matters.

Ringbom, H. (1992). On L1 Transfer in L2 Comprehension and Production. Language Learning 42:85-112.

Schumann, J. (1979). The Acquisition of English Negation by Speakers of Spanish: A Review of the Literature. In: R. Andersen (ed.): The Acquisition and Use of Spanish and English as First and Second Languages. Washington, DC: teacher of English to Speakers of Other Languages. 3-32.

Selinker, L. (1972). Interlanguage. International Review of Applied Linguistics 10: 209-231.

Skehan, P. (1989). Individual Differences in Second Language Learning. London: Edward Arnold.

Skehan, P. (1998). A Cognitive Approach to Language Learning. Oxford: Oxford University Press.

Tavakoli, P., \& Skehan, P. (2005). Strategic planning, task structure and performance testing. In R. Ellis (Ed.), Planning and Task Performance in a Second Language 239-277. Amsterdam/ Philadelphia: John Benjamins.

Vainikka, A. \& M. Young-Scholten (1994). Direct Access to X'-Theory. Evidence from Korean and Turkish Adults Learning German. Hoekstra \& Schwartz (1994: 265-316).

Vainikka, A. \& M. Young-Scholten (1996a). Gradual development of L2 phrase structure, Second Language Research 12: 7-39.

Vainikka, A. \& M. Young-Scholten (1996b). The early stages in adult L2 syntax: additional evidence from Roman speakers, Second Language Research 12: 140-176.

Weinreich, U. (1953/1968). Languages in Contact. The Hague: Mouton.

Wolfe-Quintero, K., Inagaki, S., \& Kim, H. Y. (1998). Second Language Development in Writing: Measures of Fluency, Accuracy, \& Complexity (No. 17). Honolulu: University of Hawaii Press

Åfarli, T.A. \& K.M. Eide (2003). Norsk generativ syntaks, Oslo, Novus 